This resolution they intend, if possible, shall become law. It would be well if the county officers of health urged their respective Councils to follow the lead of Lancashire in this procedure, for whatever may be the efficiency of modern methods of smoke abatement, it is quite certain that no adequate enforcement of the law is to be expected in the hundreds of petty manufacturing villages of this country at a time when even the more pro. gressive authorities of the great towns are so remiss in the discharge of their manifest duty to the public in this important matter.

\section{NOTE ON PUBLIC AND PRIVATE SLAUGHTER-HOUSES.}

By Dr. J. H. Garretr, Medical Officer of Health, Cheltenham.

Dr. HaRvey LitTLEJOHN, in reporting upon the Sheffield slaughter-houses, has brought before the public in a forcible manner the abominations that pertain to private slaughter-houses as they exist in his district. The description applies with great exactness to those in other towns. I will not repeat the numerous objectionable particulars which attach to the butchers' shambles, but for the benefit of those who are contemplating the building of abattoirs I merely desire to refer to the difficulty likely to be met with in getting the butchers to use the abattoirs when erected. We have at this time some experience in Cheltenham of this difficulty. There are slaughter-houses of two classes, viz., the registered slaughter-houses and the licensed slaughter-houses. The first were in use before the passing of the Public Health Act, r875, when it was sufficient for slaughter-houses simply to be registered, and having been placed upon the register, they remain slaughter-houses in perpetuity, if continuously used as such, and the sanitary authority has no power to close them under any circumstances so long as the existing bye-laws are barely complied with. The Local Government Board "have considered that the statutory terms do not warrant an extension of the scope of bye-laws to regulations directly affecting the structure of the premises ; " the consequence is that these old slaughter-houses are often dilapidated and altogether structurally unfit for their purpose. They are generally old tumbledown barns and hovels. The other class of slaughter-houses consists of those licensed under bye-laws made in accordance with the requirements of the Public Health Act, $\mathrm{x} 875$, and over these the sanitary authority has full powers, as they are generally only licensed for one year. It is the old registered slaughter-houses, however, that preponderate in numbers and that create the difficulty, as the owners stoutly refuse to quit them when a public abattoir has been provided. To compel them to do so the sanitary authority finds but one course open to it, which is the exceedingly costly one of first obtaining an Act of Parliament and then paying the butchers an exorbitant compensation. It is deplorable that such an obstruction should exist to the introduction of so patent a sanitary improvement as the erection of public abattoirs and the abolition of private slaughterbouses. As it is, I think it behoves each sanitary authority to take count of all the costs before embarking upon the undertaking.

\section{REPORTS OF MEDICAL OFFICERS OF HEALTH.}

Plumstead District.

In the Charlton sub-district, Mr. Bernays reports the occurrence during $189 \mathrm{I}$ of a few cases of typhus fever, the origin of which could not be traced.

Dr. Sidney Davies reports that in Plumstead"Owing to the growth of new streets being more rapid than the provision of sewers, a large number of cesspools now exist in the district, and they are increasing daily. A cesspool is a continual menace to health. If not water-tight it may pollute the sources of the drinking water supply. In any case it pollutes the air adjacent to the house it is attached to. It is therefore very regrettable that it should be necessary to continue making them. I am aware that the subject of new sewers is occupying the attention of the Board, but would press on them the urgent necessity of abolishing cesspools as quickly as possible, at whatever expense. Wherever old cesspools are found attached to houses connected with sewers, notice is served to have them filled up."

\section{COUnty of Worcester.}

Mr. Fosbroke's annual report presents a valuable digest of the annual reports of the district medical officers of health in the county of Worcester for $189 \mathrm{r}$.

He urges that the 13 out of the 43 reports thus abstracted, which have not been printed, should be printed in future in order that they may receive more complete study, and that for the sake of uniformity all reports should be printed on pages $8 \frac{1}{2}$ inches long by $5 \frac{1}{2}$ inches wide.

The introduction to the précis of the district reports is illustrated by three interesting maps. The first of these shows graphically the birth-rate, death-rate, zymotic death-rate, and infantile deathrate of each constituent district of the county, as compared with the other districts and with England and Wales as a whole.

The second gives graphically the death-rate per $r, 000$ living from phthisis, from respiratory diseases, and from cancer, urban and rural districts being distinguished. As bearing on Mr. Haviland's wellknown views, the following remarks by $\mathrm{Mr}$. Fosbroke are of interest.

"It has been alleged that large centres of the population like Manchester, Bradford, Oldham, 